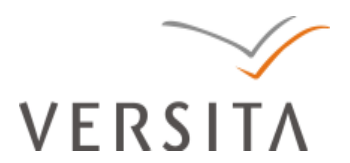

Folia Oeconomica Stetinensia

DOI: 10.2478/v10031-011-0044-8

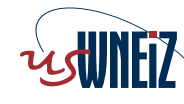

Wydzial Nauk Ekonomicznych i Zarządzania Uniwersytetu Szczecińskiego

\title{
EQUIVALENCE SCALE IN TERMS OF POLISH HOUSEHOLDS' SOURCE OF INCOME
}

Paweł Ulman, Ph.D.

Department of Statistics

Cracow University of Economics

27 Rakowicka St., 31-510 Cracow

e-mail:ulmanp@uek.krakow.pl

Received 29 September 2011, Accepted 29 December 2011

\begin{abstract}
The paper presents a comparison of the costs of Polish households by their main source of income. In order to compare these costs the author estimated three kinds of equivalence scales using the Engel method, ELES (Extended Linear Expenditure System), the demand equation and the Bernoulli well-being function. Estimation for household groups determined on account of the main source of income produced by the scales confirmed differences in households' maintenance costs compared to the costs of the reference household. A comparison of the values of equivalence scales revealed a similarity of the results produced by the ELES and the Bernoulli methods which differed from the results obtained by means of the Engel method.
\end{abstract}

Keywords: equivalence scale, households budget survey.

JEL classification: D31, D33. 


\section{Introduction}

To compare maintenance expenditures of households of various demographic composition the use is made of the equivalence scale. The scale is the basic analytical tool used to measure household material wellbeing ${ }^{1}$. It permits measuring the impact of the household's demographic composition on the household's needs, and, consequently, on family maintenance costs ${ }^{2}$. Indeed, observations reveal that the costs of attainment of the assumed wellbeing level differ depending on the household's demographic composition so that a two-person household does not need an income which is two times higher than that of a one-person household to ensure the same living standards. Thus the equivalence scale permits determining the income that a k-person household should have to attain a living standard of an n-person household of a certain income.

Unfortunately, the process of estimating equivalence scales poses numerous problems which thus far have not been resolved unequivocally ${ }^{3}$. These problems include: the choice of the shape of the utility function needed to identify the scale; specifying the dependence of function of demand on demographic variables; the manner of introducing demographic variables and the division of income and consumption among household members into the system of demand functions ${ }^{4}$. Despite these obvious hurdles, the equivalence scales are widely used in socioeconomic practice, the reason being that they play an unquestionable role in shaping social policy programmes and are the foundation of tax regimes and social wellbeing systems in any society.

The paper aims to determine the equivalence scales for Polish households broken down by their main source of income. One could hypothesise that a household's source of income affects the shape of the equivalence scale, which, of course, could be connected with the differences in income levels between groups of households. All the results presented in the paper are based on individual data derived from the 2009 household budgets survey.

\section{Calculation of equivalence scales}

Equivalence scales are either objective or subjective. The former consist of normative and empirical (statistical) scales. One example of a subjective scale is a scale determined on the basis of the Leyden approach to wellbeing calculation ${ }^{5}$. Normative scales are determined basing on expert assessment of the needs of households of different demographic composition compared to the needs of a reference household. The best known and most often used is the OECD scale, which assumes that the second and each subsequent adult person generates $70 \%$ of the costs attributed to the first adult person in the household, whereas each child is responsible for $50 \%$ 
of the costs. It was observed however that these statistics are exaggerated in respect of countries boasting an increased level of economic development. This, in turn, led to the determination of the so-called modified OECD scale ${ }^{6}$, which attributes $50 \%$ of the costs of the first adult person to each subsequent adult person and $30 \%$ to each child ${ }^{7}$. Another normative scale is the LIS scale (Luxembourg Income Study), which assumes that consumer spending depends exponentially on the number of household members $(f S)^{8}: E q_{L I S}=f s^{\varepsilon}$, where $\varepsilon$ is elasticity of the equivalence scale. This elasticity assumes values from the one-zero band and constitutes the only parameter of this equivalence scale.

Poland's Central Statistical Office has also used normative scales to research household budgets to determine the so-called consumption units, which were determined depending on caloric requirement appropriate for age and gender.

Normative scales are easy to use and remain unchanged in the long run, which explains why they are widely used in international comparisons. Their limitations include their arbitrary character, which explains why they often do not reflect the real structure of consumption in the analysed country or social group. To eliminate this shortcoming the use is made of the empirical scales.

There are two methodologies of deriving empirical equivalence scales: proxy methods and a utility-based approach. The former include the Engel method and the Rothbarth method. They permit estimating the equivalence scales on the basis of a single equation using cross-sections.

In the utility-based approach, based on households' observable consumer behaviour their preferences are inferred and these preferences are reflected in utility functions. Thus it suffices to equate the utility levels of households having different demographic structures to estimate the equivalence scale. Use of the methodology faces numerous practical problems arising from the fact that appropriate systems of the demand function do not satisfy the assumptions arising from the utility theory on the one hand and from the lack of adequate statistics ${ }^{9}$ on the other.

In this paper the author estimates the equivalence scale by means of three methodologies: the Engel method, a method based on the use of ELES (Extended Linear Expenditure System) and the method utilising the Bernoulli well-being function. These methods were chosen on account of the diversity they afford. The first two are the empirical scales, with the Engel method being a proxy method and the ELES method relating to utility. The third method gives a subjective equivalence scale.

The Engel method is grounded in two regularities. The first implies that an increase in household's total income or expenditure is accompanied by a falling share of food expenditure in total expenditure, which results from a lower increase in demand for food than for other 
goods against a growing income of the household. The other regularity is that more populous households spend more on food than less populous households of the same income. This implies that if we equate the share of food expenditure of households (recognised to be a reliable indicator of wellbeing) of different demographic composition, we obtain the income of comparable households, which can be juxtaposed to produce an equivalence scale. The Engel method has its limitations too. It is criticised for its apparent lack of theoretical foundations. Moreover, the assumption whereby households whose share of food expenditures is identical report the same level of expenditures (income) regardless of the type of household has been found to be problematic.

In yet another application of the Engel method, in order to determine households' relative income requirement expenditures, basic need items instead of food expenditure are used. This way of determining equivalence scales was used in Canada, where the basic needs are considered to involve food, clothing, housing and health.

The food or basic need items function can take the following form:

$$
\ln w=\beta_{0}+\beta_{1} \ln f_{s}+\beta_{2} \ln y+\sum_{h=3}^{k} \beta_{h} z_{h}+e
$$

where: $w$ represents food expenditure or expenditure on satisfying basic needs; $f_{s}$ - number of persons in the household; $y$ - household's income (total expenditure); $z_{h}$ - set of variables characterising the household.

In this case, the equivalence scale will be derived by comparing the food expenditures or basic need items expenditures in the household under research and the reference household which gives the following equation:

$$
E q_{E N}=\left(\frac{f s}{f s_{0}}\right)^{-\left(\frac{\beta_{1}}{\beta_{2}-1}\right)} \exp \left(\frac{\sum_{h=3}^{k} \beta_{h} z_{h 0}-\sum_{h=3}^{k} \beta_{h} z_{h}}{\beta_{2}-1}\right)
$$

where the subscript " 0 " with variables " $f s$ " and " $z_{h}$ " relates to the reference household.

One of the methods of estimation of equivalence scales based on utility is Lluch's ${ }^{10}$ ELES method (Extended Linear Expenditure System), which assumes that the consumer maximises the utility function in a limited budget. The demand system represented by ELES considers not just a single group of expenditures as in the case of the Engel method, but all expenditures on goods and services incurred by the household. The ELES method is based on the Stone-Geary utility function: 


$$
U=\sum_{i=1}^{s} \beta_{i} \ln \left(\frac{q_{i}}{m_{i}}-\gamma_{i}\right)
$$

where:

$q_{i}$ is expenditure on a good $i$,

$m_{i}$ - coefficient correcting expenditure on good $i$ on account of the household's demographic characteristics,

$\beta_{i}$ and $\gamma_{i}$ are parameters, the first of which is construed as marginal share in expenditures and the second represents the level of the so-called necessary expenditures.

The correction coefficient $m_{i}$ is determined based on the formula:

$$
m_{i}=1+d_{i}{ }^{\prime} z
$$

where $z$ is the vector of demographic variables, and $d$ is the vector of coefficients.

In the case of this system, demand equations for the current period will be written as follows:

$$
q_{i}=a_{i}+b_{i} x+c_{i}{ }^{\prime} z
$$

where:

$$
a_{i}=\gamma_{i}-b_{i} \sum_{j} \gamma_{j}
$$

$b_{i}=\beta_{i} \mu$ with $\mu$ representing the marginal propensity to consume;

$c_{i h}=\gamma_{i} d_{i h}-b_{i} \sum_{j} \gamma_{j} d_{j h}$ (goods: $i, j=1, \ldots, s ;$ demographic characteristics: $\left.h=1, \ldots, \mathrm{k}\right)^{11}$.

The estimation of the system of demand equations is effected by means of the method of least squares, in line with the Seemingly Unrelated Regressions methodology. Based on these estimations, the value of the cost function for the researched household and the reference household is determined, and their quotient produces the value of the equivalence scale.

The scale determined on the basis of the Bernoulli well-being function is used as a subjective equivalence scale:

$$
W(x)=\gamma_{0}+\gamma_{1} \ln x=\frac{\ln x-\mu}{\sigma}
$$

where $x$ represents a household's virtual income determined subjectively for a given wellbeing level within the framework of a system of questions assessing income, while $\gamma_{0}$ and $d \gamma_{1}$ or alternatively $\sigma=1 / \gamma_{1}$ and $\mu=\gamma_{0} / \gamma_{1}$ are parameters of this function. 
Another way of expressing the Bernoulli well-being function is the Leyden model, which permits the estimation of the above parameters. Additionally, one of the parameters $\left(\gamma_{0}\right.$ or $\left.\gamma_{1}\right)$ may be made variable, which permits making the well-being functions dependent upon the household characteristics. Ultimately, in this extended approach, the Bernoulli well-being function is written as follows:

$$
W(x \mid f n, y, z)=\gamma_{00}+\gamma_{01} \ln f n+\gamma_{02} \ln y+\sum_{h=3}^{k} \gamma_{0 h} z_{h}+\gamma_{1} \ln x
$$

If we assume that $x=y$ and then group parameters, the Bernoulli well-being function will have the form:

$$
W(y \mid f n, z)=\delta_{0}+\delta_{1} \ln f n+\delta_{2} \ln y+\sum_{h=3}^{k} \delta_{h} z_{h}
$$

The comparison of the function of wellbeing in the researched household and the reference household produces an equivalence scale in the form of:

$$
E q_{B E}=\left(\frac{f_{S}}{f_{s_{0}}}\right)^{-\left(\frac{\delta_{1}}{\delta_{2}}\right)} \exp \left(\frac{\sum_{h=3}^{k} \delta_{h} z_{h 0}-\sum_{h=3}^{k} \delta_{h} z_{h}}{\delta_{2}-1}\right)
$$

\section{Results of empirical research}

All of the below results were obtained from individual data derived from research into 2009 household budgets survey. The household budget survey is the basic source of information on the revenues, outgoings, quantitative food consumption and other aspects of the living conditions of particular groups of the population in Poland. It is based on the sampling method which allows for the generalisation of the results to the whole population of households. The monthly rotation of households assumes that every month of the year a different group of households participates in the survey. The entire data set in 2009 comprises 37,302 household observations.

Given that in determining the equivalence scales, household socio-demographic characteristics play an important role, only such structures as relate to this situation are subsequently presented.

In the researched group of households, $61.69 \%$ of household heads are married, and $56.94 \%$ of household heads are male. With a view to illustrating households' demographics, in Table 1 the author presents a household structure by age groups including children aged 6 or under, children aged 7-14, persons aged 15-64 and persons in the 65 and over age group. 
Table 1. Household structure by number of persons in selected age groups

\begin{tabular}{|c|c|c|c|c|}
\hline \multirow{2}{*}{ Number of householders } & \multicolumn{3}{|c|}{ Age } \\
\cline { 2 - 5 } & 6 or under & $7-14$ & $15-64$ & 65 and over \\
\hline 0 & 84.40 & 77.78 & 16.50 & 71.26 \\
\hline 1 & 12.34 & 14.97 & 19.80 & 6.92 \\
\hline 2 & 2.94 & 5.85 & 33.55 & 0.08 \\
\hline 3 & 0.29 & 1.15 & 16.60 & 0.00 \\
\hline 4 and over & 0.03 & 0.25 & 13.63 & 100.00 \\
\hline Total & 100.00 & 100.00 & 100.09 & \\
\hline
\end{tabular}

Source: Author's own calculations.

$84.4 \%$ of households reveal no children aged 6 or under, over $70 \%$ of households have no children aged 7-14 and senior persons (aged 65 or over). Most households are composed of 2 persons aged 15-64 (33.55\%), and no households reveal more than three senior persons.

Nearly half of the households live off hired labour (49.09\%), 28.47\% live off retirement pension, $7.67 \%$ live off disability pension, $6.91 \%$ work for their own account, and least often households support themselves from unearned sources of income $(4.10 \%)$ with $3.76 \%$ of households earning a living from agriculture.

Table 2. The structure of household expenditure by source of income

\begin{tabular}{|c|c|c|c|c|c|c|c|}
\hline \multirow[b]{2}{*}{ Expenditure type } & \multicolumn{6}{|c|}{ Main source of household's income } & \multirow[b]{2}{*}{ Total } \\
\hline & $\begin{array}{l}\text { hired } \\
\text { labour }\end{array}$ & farm & self-employed & pension & $\begin{array}{l}\text { disability } \\
\text { pension }\end{array}$ & $\begin{array}{c}\text { unearned source } \\
\text { of income }\end{array}$ & \\
\hline 1 & 23.77 & 33.16 & 20.74 & 27.81 & 30.23 & 26.67 & 25.09 \\
\hline 2 & 2.85 & 2.54 & 2.43 & 2.52 & 2.68 & 3.20 & 2.72 \\
\hline 3 & 5.88 & 5.95 & 6.22 & 3.21 & 2.92 & 5.31 & 5.22 \\
\hline 4 & 18.21 & 17.12 & 17.96 & 23.22 & 25.19 & 24.94 & 19.65 \\
\hline 5 & 5.60 & 5.65 & 5.78 & 4.95 & 4.49 & 3.52 & 5.38 \\
\hline 6 & 3.96 & 4.05 & 4.01 & 8.18 & 7.98 & 3.43 & 5.01 \\
\hline 7 & 11.20 & 9.32 & 12.11 & 5.85 & 4.27 & 7.44 & 9.69 \\
\hline 8 & 4.58 & 4.59 & 4.86 & 4.32 & 4.53 & 4.29 & 4.54 \\
\hline 9 & 8.70 & 5.59 & 10.02 & 6.12 & 5.31 & 7.73 & 7.98 \\
\hline 10 & 1.53 & 0.74 & 1.64 & 0.32 & 0.42 & 1.13 & 1.20 \\
\hline 11 & 2.49 & 0.80 & 2.93 & 1.17 & 1.35 & 3.73 & 2.17 \\
\hline 12 & 7.40 & 6.65 & 6.69 & 6.00 & 5.22 & 5.57 & 6.86 \\
\hline 13 & 3.83 & 3.85 & 4.59 & 6.33 & 5.40 & 3.05 & 4.48 \\
\hline Aver. Expenditure & 3164.07 & 3067.77 & 4081.74 & 1983.27 & 1546.36 & 1743.50 & 2706.47 \\
\hline $\begin{array}{l}\text { Aver. number } \\
\text { of householders }\end{array}$ & 3.35 & 4.20 & 3.35 & 2.02 & 2.01 & 2.50 & 2.90 \\
\hline Expend. per person & 941.57 & 711.99 & 1208.03 & 1045.86 & 839.38 & 737.23 & 956.71 \\
\hline
\end{tabular}

1 - food; 2 - alcoholic beverages and other stimulants; 3 - clothing and footwear; 4 - use of dwelling; 5 - dwelling furnishings; 6 - healthcare; 7 - transport; 8 - communication; 9 - leisure and culture; 10 - education; 11 - restaurants and hotels; 12 - other expenditures on goods and services; 13 - remaining expenditures.

Source: Author's own calculations. 
Table 2 shows the structure of household expenditures broken down by source of income.

The largest share in total expenditure is revealed by expenditure on food followed by the use of dwelling expenditure. For the less affluent social groups these two kinds of expenditure account for over $50 \%$ of total expenditure (households supporting themselves from disability pension or unearned sources of income). If one assumes that the share of food expenditure in the total expenditure reflects a household's economic status then the most affluent are the households whose heads are self-employed, and the least affluent are families living off agriculture. In terms of the number of householders, families living off agriculture are the most populous, which translates into the lowest expenditure per person. The highest expenditure per person is revealed by households whose head is self-employed, followed by household living off retirement pensions.

Table 3 shows the structure of the biological type of household by the main source of income. This analysis reveals which types of households predominate and which are rare for a given source of income.

Table 3. The structure of the biological type of household by main source of income

\begin{tabular}{|c|c|c|c|c|c|c|c|}
\hline \multirow{2}{*}{$\begin{array}{l}\text { Biological type } \\
\text { of household }\end{array}$} & \multicolumn{6}{|c|}{ Main source of household's income } & \multirow[b]{2}{*}{ Total } \\
\hline & hired labour & farm & self-employed & pension & $\begin{array}{l}\text { disability } \\
\text { pension }\end{array}$ & $\begin{array}{c}\text { unearned source } \\
\text { of income }\end{array}$ & \\
\hline 1 & 12.02 & 6.72 & 14.23 & 32.64 & 11.08 & 7.33 & 17.53 \\
\hline 2 & 16.95 & 7.68 & 20.57 & 1.93 & 2.78 & 4.66 & 10.97 \\
\hline 3 & 17.62 & 11.30 & 23.01 & 0.64 & 1.88 & 4.79 & 11.19 \\
\hline 4 & 5.07 & 7.76 & 6.24 & 0.13 & 0.77 & 2.04 & 3.41 \\
\hline 5 & 1.82 & 4.90 & 1.96 & 0.08 & 0.29 & 1.72 & 1.34 \\
\hline 6 & 2.26 & 0.27 & 1.42 & 0.15 & 1.38 & 9.25 & 1.75 \\
\hline 7 & 0.15 & 0.00 & 0.41 & 0.02 & 0.31 & 0.45 & 0.15 \\
\hline 8 & 13.29 & 31.83 & 11.23 & 3.38 & 3.58 & 3.23 & 9.95 \\
\hline 9 & 2.98 & 1.19 & 1.40 & 1.74 & 2.86 & 7.95 & 2.64 \\
\hline 10 & 0.24 & 0.28 & 0.24 & 0.11 & 0.26 & 0.15 & 0.20 \\
\hline 11 & 1.68 & 2.56 & 1.07 & 0.78 & 1.16 & 1.87 & 1.39 \\
\hline 12 & 10.94 & 5.78 & 8.71 & 43.67 & 57.28 & 45.02 & 24.80 \\
\hline 13 & 14.97 & 19.74 & 9.51 & 14.71 & 16.36 & 11.55 & 14.68 \\
\hline Total & 49.09 & 3.76 & 6.91 & 28.47 & 7.67 & 4.10 & 100.0 \\
\hline
\end{tabular}

1 - married couple without children; 2 - married couple with 1 child; 3 - married couple with 2 children; 4 - married couple with 3 children; 5 - married couple with 4 and more children; 6 - mother with children; 7 - father with children; 8 - married couple with children and other persons; 9 - mother with children and other persons; 10 - father with children and other persons; 11 - other persons with children; 12 - one-person household; 13 - other.

Source: Author's own calculations. 
In the case of the first three types of the main source of income there is prevalence of those households prevail that consist of married couples with children being dependants, whereas the one-person household predominates in the last three types. In order to present the results of estimation of the equivalence scales let us assume the following variables describing household composition:

$z_{3}$ - number of children aged 6 or under $^{12}$;

$z_{4}-$ number of children aged 7-14;

$z_{5}$ - number of adult householders aged 15-64;

$z_{6}$ - number of adult householders aged 65 or over;

$z_{7}$ - household's head's marital status;

$z_{8}$ - household's head's gender.

In the case of each equivalence scale presented in the paper, apart from the above variables, the author also considers the logarithm of the total number of householders and a logarithm of income for the Bernoulli scale and the Engel scale, and for the ELES scale the author admits income. All of the above equivalence scales were estimated for the entire group and subgroups isolated on account of the household's source of income. Table 4 presents selected results of estimation of models (1), (5) and (8) for all households.

Table 4. The results of estimation of models for the Engel, ELES and Bernoulli equivalence scales obtained on the basis of the entire group of households

\begin{tabular}{|c|c|c|c|c|c|c|c|c|}
\hline \multirow{3}{*}{ Variable } & Bernoulli & Engel & \multicolumn{6}{|c|}{ ELES } \\
\hline & \multirow[b]{2}{*}{ estimate } & \multirow[b]{2}{*}{ estimate } & \multicolumn{6}{|c|}{ estimate } \\
\hline & & & $\begin{array}{c}\text { expenditure } \\
1^{* *}\end{array}$ & $\begin{array}{c}\text { expenditure } \\
3\end{array}$ & $\begin{array}{c}\text { expenditure } \\
45\end{array}$ & $\begin{array}{c}\text { expenditure } \\
6\end{array}$ & $\begin{array}{c}\text { expenditure } \\
78\end{array}$ & $\begin{array}{c}\text { other } \\
\text { expenditure }\end{array}$ \\
\hline Intercept & 4.302 & 3.973 & 205.4 & 44.15 & 369.7 & 77.34 & 106.9 & 280.9 \\
\hline$z_{3}$ & -0.039 & -0.055 & 30.98 & $3.73^{*}$ & -49.99 & $4.43^{*}$ & -28.02 & -49.38 \\
\hline$z_{4}$ & -0.048 & $-0.008^{*}$ & 62.87 & $-4.62^{*}$ & -84.82 & -19.95 & -59.68 & -45.98 \\
\hline$z_{5}$ & -0.030 & 0.027 & 105.1 & -19.09 & -63.58 & -14.92 & -36.42 & -57.42 \\
\hline$z_{6}$ & -0.073 & 0.047 & 109.0 & -55.46 & -79.77 & 45.18 & -120.2 & -172.9 \\
\hline $\begin{array}{l}\text { ln of income/ } \\
\text { income }\end{array}$ & 0.414 & 0.244 & 0.029 & 0.030 & 0.093 & 0.015 & 0.072 & 0.139 \\
\hline $\begin{array}{l}\text { In of the total } \\
\text { number of persons }\end{array}$ & 0.242 & 0.418 & 74.09 & 67.1 & 213.9 & 15.71 & 172.8 & 144.0 \\
\hline$z_{7}$ & 0.042 & 0.115 & 83.34 & $1.59^{*}$ & 27.10 & 36.09 & 24.72 & 26.08 \\
\hline$z_{8}$ & $0.004^{*}$ & -0.014 & $-2.88^{*}$ & -5.50 & $-11.38^{*}$ & -17.35 & 33.17 & $9.91^{*}$ \\
\hline
\end{tabular}

* statistically insignificant estimate at significance level of $0.1 ;{ }^{* *}$ marking of expenditure as in table 2 .

Source: Author's own calculations. 
The results of the estimation of the above-mentioned models as presented in Table 4 form the foundation for attainment of the values of the equivalence scales on the basis of equations (7-9), (2) and (5) $)^{13}$ respectively. Tables 5-7 present the values of equivalence scales determined on the basis of the methods presented in this paper. In the case of Table 5 the results are for all households and they assume that the reference household is constituted by a married couple aged 15-64 having no children, whereas in the second case (Table 6 and 7) the results are grouped on account of the household's source of income. The differences in the households' demographic structure in the researched household categories are behind the assumption of two types of the reference household.

Table 5. The values of equivalence scales for all households - the reference household: a married couple aged 15-64 without children

\begin{tabular}{|c|c|c|c|c|}
\hline \multirow{3}{*}{$\begin{array}{l}\text { Equivalence } \\
\text { scale }\end{array}$} & \multicolumn{4}{|c|}{ Single } \\
\hline & \multicolumn{2}{|c|}{ woman aged } & \multicolumn{2}{|c|}{ man aged } \\
\hline & $15-64$ & 65 and over & $15-64$ & 65 and over \\
\hline ELES & 0.618 & 0.623 & 0.499 & 0.504 \\
\hline Bernoulli & 0.737 & 0.776 & 0.737 & 0.776 \\
\hline Engel & 0.576 & 0.591 & 0.565 & 0.580 \\
\hline \multirow{3}{*}{$\begin{array}{l}\text { Equivalence } \\
\text { scale }\end{array}$} & \multicolumn{4}{|c|}{ Married coupe of persons aged } \\
\hline & \multirow[b]{2}{*}{$\begin{array}{c}65 \text { and over without } \\
\text { children }\end{array}$} & \multicolumn{3}{|c|}{$15-64$} \\
\hline & & $\begin{array}{l}\text { with child aged } 6 \\
\text { or under }\end{array}$ & with child aged $7-14$ & with two children \\
\hline ELES & 0.693 & 1.134 & 1.086 & 1.163 \\
\hline Bernoulli & 1.109 & 1.227 & 1.208 & 1.274 \\
\hline Engel & 1.054 & 1.164 & 1.251 & 1.365 \\
\hline
\end{tabular}

Source: Author's own calculations.

The equivalence scales obtained are markedly ,flatter” than the OECD scale. The least flat is the scale obtained by means of the Engel method, although in the case of farmers the least flat is the scale derived from the ELES method, which may result from the large share of expenditures incurred to satisfy basic needs of households living off agriculture. It should also be noted that a single child aged 6 or under generates a higher cost than a single child aged 7-14, which is confirmed by the majority of estimations of equivalence scales. Only in a rare few instances is the costs of maintenance of a single child aged 7-14 higher than the cost of maintenance of a younger child. This situation manifests itself only on the Engel scale. According to the ELES scale in all households the maintenance cost of senior married couples is lower than the cost incurred by married couples aged 15-64, whereas both the Bernoulli and Engle scales show it to be higher. In respect of farmer households, the maintenance cost of senior married couples is 
not higher than the same cost incurred by a married couple of persons aged 15-64. Single men mostly generate lower costs than single women and that holds true regardless of age. The ELES and Bernoulli scales reveal similar values, whereas the values on the Engel scale diverge from the values of the above scales. Yet in the case of farmers, the Engel and Bernoulli scales reveal like results. The largest differences in the values of equivalence scales determined for a given group of households were ascertained for households living off agriculture and the smallest for households living off unearned sources of income and retirement pension.

Table 6 . The values of equivalence scales by household's main source of income - the reference household: married couple aged 15-64 without children

\begin{tabular}{|c|c|c|c|c|c|c|}
\hline SI & \multirow{3}{*}{ Scale } & \multicolumn{5}{|c|}{ Household type } \\
\hline \multirow{5}{*}{ 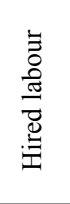 } & & \multicolumn{2}{|c|}{ Single person aged $15-64$} & \multicolumn{3}{|c|}{ Married couple aged $15-64$ with a child } \\
\hline & & woman & $\operatorname{man}$ & aged 6 or under & $7-14$ & two children \\
\hline & ELES & 0.841 & 0.814 & 1.069 & 1.076 & 1.117 \\
\hline & Bernoulli & 0.815 & 0.805 & 1.065 & 1.057 & 1.095 \\
\hline & Engel & 0.587 & 0.570 & 1.179 & 1.247 & 1.375 \\
\hline \multirow{5}{*}{ 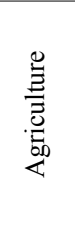 } & \multirow{2}{*}{ Scale } & \multirow{2}{*}{$\begin{array}{c}\text { Married couple } \\
\text { of persons aged } \\
65+ \\
\end{array}$} & \multicolumn{4}{|c|}{ Married couple aged $15-64$ with a child } \\
\hline & & & aged 6 or under & aged 6 or under & aged 6 or under & aged 6 or under \\
\hline & ELES & 0.783 & 1.667 & 1.594 & 2.371 & 2.494 \\
\hline & Bernoulli & 1.000 & 1.154 & 1.108 & 1.227 & 1.279 \\
\hline & Engel & 0.944 & 1.235 & 1.235 & 1.435 & 1.435 \\
\hline \multirow{5}{*}{ 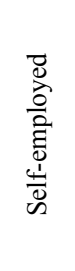 } & \multirow[b]{2}{*}{ Scale } & \multicolumn{5}{|c|}{ Married couple of persons aged $15-64$ with a child } \\
\hline & & aged 6 or under & $7-14$ & two children & $\begin{array}{c}\text { aged } 6 \text { or under } \\
\text { and a person } \\
\text { aged } 65+\end{array}$ & $\begin{array}{c}\text { two children and } \\
\text { a person aged } \\
65+\end{array}$ \\
\hline & ELES & 1.071 & 1.024 & 1.092 & 1.209 & 1.200 \\
\hline & Bernoulli & 1.074 & 1.076 & 1.129 & 1.129 & 1.174 \\
\hline & Engel & 1.160 & 1.225 & 1.361 & 1.467 & 1.592 \\
\hline \multirow{5}{*}{ 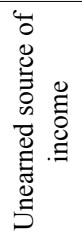 } & \multirow[b]{2}{*}{ Scale } & \multirow{2}{*}{$\begin{array}{l}\text { Man without } \\
\text { children }\end{array}$} & \multicolumn{4}{|c|}{ Woman aged $15-64$ with a child } \\
\hline & & & $\begin{array}{l}\text { without } \\
\text { children }\end{array}$ & aged 6 or under & $7-14$ & two children \\
\hline & ELES & 0.821 & 0.882 & 1.077 & 0.968 & 1.095 \\
\hline & Bernoulli & 0.709 & 0.709 & 0.923 & 0.911 & 1.028 \\
\hline & Engel & 0.592 & 0.561 & 0.905 & 0.905 & 1.196 \\
\hline
\end{tabular}

SI - household's main source of income.

Source: Author's own calculation. 
Table 7. The values of equivalence scales by household's main source of income - the reference household: married couple aged $65+$ without children

\begin{tabular}{|c|c|c|c|c|c|c|}
\hline SI & \multirow{3}{*}{ Scale } & \multicolumn{5}{|c|}{ Household type } \\
\hline \multirow{5}{*}{ 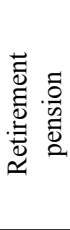 } & & \multicolumn{2}{|c|}{ Woman aged $65+$} & \multicolumn{2}{|c|}{ Man aged $65+$} & \multirow{2}{*}{$\begin{array}{c}\text { Married couple of persons } \\
\text { aged } 65+\text { with a person } \\
\text { aged } 15-64\end{array}$} \\
\hline & & single person & $\begin{array}{c}\text { with a person } \\
\text { aged } 15-64\end{array}$ & single person & $\begin{array}{c}\text { with a person } \\
\text { aged } 15-65\end{array}$ & \\
\hline & ELES & 0.819 & 1.009 & 0.851 & 1.046 & 1.123 \\
\hline & Bernoulli & 0.804 & 1.019 & 0.804 & 1.019 & 1.121 \\
\hline & Engel & 0.583 & 0.929 & 0.567 & 0.906 & 1.279 \\
\hline \multirow{5}{*}{ 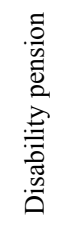 } & \multirow[b]{2}{*}{ Scale } & \multicolumn{2}{|c|}{ Woman aged $65+$} & \multicolumn{2}{|c|}{ Man aged $65+$} & \multirow{2}{*}{$\begin{array}{c}\text { Married couple of persons } \\
\text { aged } 65+\text { with a person } \\
\text { aged } 15-64\end{array}$} \\
\hline & & single person & $\begin{array}{c}\text { with a person } \\
\text { aged } 15-64\end{array}$ & single person & $\begin{array}{c}\text { with a person } \\
\text { aged } 15-65\end{array}$ & \\
\hline & ELES & 0.943 & 1.368 & 0.838 & 1.248 & 1.317 \\
\hline & Bernoulli & 0.870 & 1.103 & 0.801 & 1.016 & 1.108 \\
\hline & Engel & 0.558 & 0.877 & 0.558 & 0.877 & 1.303 \\
\hline
\end{tabular}

SI - household's main source of income.

Source: Author's own calculation.

\section{Conclusions}

The paper attempts to evaluate the equivalence scales by means of three methods for all households and for households broken down by the household's main source of income. The results point out a certain tendency for the values produced by the scales to change, these however are not always unambiguous. The estimation of scales for household groups in terms of the main source of income reveals variations in the values of maintenance costs compared to the reference household. This may be engendered by different consumption patterns and variations in the economic status of the researched households or by both these factors combined. The similarity of the results produced by the ELES and Bernoulli methods should favour their more extensive use than of the Engel scale which is believed to overstate the maintenance costs of additional householders. Of these two, the Bernoulli scale is easier to use. It appears that the use of additional information on the household's subjectively assessed level of wellbeing is an attractive alternative to utility-based scales or proxy scales.

\section{Notes}

1 See Szulc (1995), pp. 37-38.

2 See Rusnak (2007), pp. 112-113. 
3 Literature discussing calculation and the use of equivalence scales is very extensive. The authors who deserve mentioning include Muellbauer (1974); Deaton, Muellbauer (1980), (1986); Phipps (1998); Blackorby, Donaldson (1987), (1993); Jenkin, Cowell (1994); Chatterjee, Michelini (1998); Szulc (1999), (2003); Lewbel (1991); Blundel, Lewbel (1991).

4 See Rusnak (2007), p. 114.

5 For more information, see Kot (2000), pp. 38-53.

6 There are two main OECD equivalence scales: the so-called Oxford scale of 1982 (The OECD List..., 1982) and the modified scale of 1994 (Hagenaars, Vos, Zaidi, 1994), although in the most recent OECD reports which compare the inequalities of income distribution and poverty between countries, a square root of the number of persons in the household has been used to generate equivalents (see e.g. Growing Unequal?... (2008), p. 41).

7 See Ciecieląg (2008), p. 75.

8 See Buhmann and others (1988), p. 119.

9 More information on problems underlying the use of utility-based equivalence scales can be found in Rusnak (2007), pp. 121-124. There readers will also find information on limiting conditions imposed upon the demand function.

${ }^{10}$ Lluch (1973), pp. 21-31.

11 The details underlying determination of the values of individual parameters of the utility function and a corresponding cost function can be found in Ciecieląg (2008), pp. 86-88 and in Gaag, Smolensky (1982), pp. 27-28.

12 Number of years finished.

13 The details of how the values of equivalence scale were obtained for the ELES method can be found in Ciecielagg (2008), pp. 86-88.

\section{References}

Blackorby, C., Donaldson, D. (1987). Welfare Ratios and Distributionally Sensitive Cost-benefit Analysis. Journal of Population Economics, 34(3), 265-290.

Blackorby, C., Donaldson, D. (1993). Household Equivalence Scales and Welfare Comparisons: A Comment. Journal of Public Economics, 50(1), 143-146.

Blundel, R.W., Lewbel, A. (1991). The Information Content of Equivalence Scales. Journal of Econometrics, 50(1), 49-68.

Buhmann, B., Rainwater, L., Schmaus, G., Smeeding, T.M. (1988). Equivalence Scales, Wellbeing, Inequality and Poverty: Sensitivity Estimates Across Ten Countries Using the Luxembourg Income Study Database. Review of Income and Wealth, 34(2), 115-142. DOI: 10.1111/j.1475-4991.1988.tb00564.x.

Chatterjee, S., Michelini, C. (1998). Household Consumption Equivalence Scales: Some Estimates from New Zealand Household Expenditure and Income Survey. Australian and New Zealand Journal of Statistics, 40(2), 141-150.

Ciecieląg, J. (2008). Skale ekwiwalentności - metody szacowania i ich wykorzystanie. In: Pomiar ubóstwa. Zmiany koncepcji i ich znaczeni, I. Tropińska (Eds.), 73-97. Warszawa: IPiSS. 
Deaton, A., Muellbauer, J. (1980). Economics and Consumer Behaviour. Cambridge: Cambridge University Press.

Deaton, A., Muellbauer, J. (1986). On Measuring Child Costs: with Application to Poor Countries. Journal of Population Economics, 94(4), 720-744.

Gaag, van der J., Smolensky, E. (1982). True Household-equivalence Scales and Characteristics of the Poor In the U.S. Review of Income and Wealth, 28(1), 17-28. DOI: 10.1111/j.14754991.1982.tb00603.x.

Growing Unequal? Income Distribution and Poverty in OECD Countries. (2008). OECD Publishing, www.oecd.org/els/social/inequality/GU.

Hagenaars, A., de Vos, K., Zaidi, M.A. (1994). Poverty Statistics in the Late 1980s: Research Based on Micro-data. Luxembourg: Office for Official Publications of the European Communities.

Jenkins, S.P., Cowell, F.A. (1994). Parametric Equivalence Scales and Scale Relativities. The Economic Journal, 104(425), 891-900.

Kot, S.M. (2000). Ekonometryczne modele dobrobytu. Warszawa-Kraków: Wydawnictwo Naukowe PWN.

Lewbel, A. (1991). Cost of Characteristics Indices and Households Equivalences Scales. European Economic Review, 35(6), 1277-1293.

Lluch, C. (1973). The Extended Linear Expenditure System. European Economic Review, 4(1), 21-31. DOI:10.1016/0014-2921(73)90028-7.

Muellbauer, A. (1974). Households Composition, Engel Curves and Welfare Comparisons between Households: a duality Approach. European Economic Review, 5(2), 103-122. DOI:10.1016/0014-2921(74)90018-X.

Phipps, S. (1998). What is the Income „Cost of the Child”? Exact Equivalence Scales for Canadian Two-Parent Families. Review of Economics and Statistics, 80(1), 157-164.

Rusnak, Z. (2007). Statystyczna analiza dobrobytu ekonomicznego gospodarstw domowych. Wrocław: Wydawnictwo Akademii Ekonomicznej we Wrocławiu.

Szulc, A. (1995). Skale ekwiwalentności w pomiarze dobrobytu gospodarstw domowych. Polityka Społeczna, 8, 37-42.

Szulc, A. (1999). Almost Ideal Demand System with Demographic Variables: Estimates for Poland with Applications to Welfare Measurement. Research Bulletin, Research Centre for Economic and Statistical Studies, Warsaw, 7(3/4), 61-80.

Szulc, A. (2003). Is it Possible to Estimate Reliable Household Equivalence Scales. Statistics in Transition, 6(4), 589-611.

OECD. (1982). The OECD List of Social Indicators. Paris: OECD. 